\title{
Implementation of Multi Objective Optimization on the Basic of Ratio Analysis Method in Decision Support System for Hope Family Program Assistance Recipients in Kelinjau Ulu Village
}

\author{
Arsita * \\ STMIK Widya Cipta Dharma, \\ Samarinda, 75123, Indonesia \\ arsita582@gmail.com \\ *Corresponding author
}

\author{
Salmon (it) \\ STMIK Widya Cipta Dharma, \\ Samarinda, 75123, Indonesia \\ salmon@wicida.ac.id
}

\author{
Heny Pratiwi (i) \\ STMIK Widya Cipta Dharma, \\ Samarinda, 75123, Indonesia \\ heny@wicida.ac.id
}

Received: 2021-10-03; Revised: 2021-08-02; Accepted: 2021-10-18; Published: 2021-12-01

\begin{abstract}
The research was conducted to be able to create a decision support system for beneficiaries of the Family Hope Program or "Program Keluarga Harapan (PKH)" with the Multi Objective Optimization Method On The Basic Of Ratio Analysis (Moora), which later if this research is successful it can assist aid managers in making decision making for program aid recipients Family Hope "PKH". This research was conducted at the office of the Family Hope Program "PKH" assistance manager in Kelinjau Ulu Village, Muara Analog District, the data collection method used was interviews which asked questions related to "PKH" beneficiaries. By means of observation, namely making direct observations at the "PKH" Assistance Manager office. In this study, the system development method used is the decision support system development method. The model with the decision support software used is the Visual Basic.NET programming language, the database used by Microsoft Access. The final result of this research is in the form of a Decision Support System for beneficiaries of the Family Hope Program "PKH" Using the Multi Objective Optimization Method on the Basic of Ratio Analysis (Moora) which can facilitate more precise selection of "PKH" aid recipients.
\end{abstract}

Keywords- Decision Support System, Family Hope Program, Assistance, MOORA.

\section{INTRODUCTION}

The Family of Hope Program "PKH" is a program of providing conditional social assistance to poor families who are designated as "PKH" beneficiary families. The criteria for "PKH" beneficiary families are poor families who meet at least one of the requirements, such as pregnant / breastfeeding mothers, having children aged 0 months to 5 years 11 months. Having SD / MI or equivalent children, having SMP / MTs children or equivalent. Have a high school / MA or equivalent. "PKH" is also given to families with children aged 6 to 21 who have not completed the 12 year compulsory education. In addition, "PKH" is also given to elderly families, preferably starting from 70 years and people with disabilities are prioritized for people with severe disabilities. (Ladjamuddin, 2012)

With the amount of assistance available to rural communities, more and more people are the recipients of this assistance. which allows one community to receive several types of assistance. In this "PKH" assistance prioritized people who were truly underprivileged and immediately received data on aid recipients from the East Kutai City Government without seeing the actual conditions in Kelinjau Ulu Village, Muara Ancalong District. In this way, many recipients were not on target. If there are people who are still sufficiently fortunate to be "PKH" recipients, there will be potential for jealousy towards fellow citizens. (Badudu \& Zain, 2011)

To overcome the above problems, a decision support system was created to assist in the process of determining which communities are entitled to receive "PKH" assistance. It is hoped that the creation of a Decision Support System will solve the problems faced and produce recommendations for decisions that can help "PKH" assistance managers to determine which communities are truly entitled to receive "PKH" assistance. (Lamsi, 2019)

\section{LITERATURE REVIEW}

\section{A. System}

According to Romney and Jhon (2014), a system is a series of two or more interconnected components that interact to achieve a goal. According to Mulyadi (2010), the system is basically a group of elements that are closely related to one another, which function together to achieve certain goals. 


\section{B. Decision}

According to Nofriansyah (2017), a decision is an activity to choose a strategy or action in solving the problem. The act of choosing a strategy or action that the manager believes will provide the best solution for this in decision making.

\section{Family Hope Program "PKH”}

The Ministry of Social Affairs (Deposes) together with cross-sectoral starting in July 2007 launched the Family Hope Program "PKH". The family hope program or what is often called "PKH" is a social assistance program to households that meet certain qualifications by imposing requirements in order to change poor behavior. (Madcoms, 2011) The program referred to is a program of giving cash to Very Poor Households (RTSM) and RTSM family members are required to implement the terms and conditions that have been set. Such programs are known internationally as the conditional cash transfer (CCT) program or the Conditional Cash Transfer program. These requirements can be in the form of attendance at educational facilities (for example for school age children)

\section{Decision Support System}

According to Wibowo (2011), a decision support system is a computer-assisted decision-making process to help decision makers by using certain data and models to solve some unstructured problems. The existence of a decision support system in a company or organization is not to replace the tasks of decision makers, but is a tool that helps them in decision makers. By using data that is processed into information to make decisions from semistructured problems. In the implementation of a Decision Support System, the results of the decisions of the system are not things that become a benchmark, decision making remains in decision making. The system only produces output that calculates data as a decision maker considers. (Rosa \& Salahuddin, 2013)

\section{E. Multi Objective Optimization Method On The Basic Of Ratio Analysis (MOORA)}

According to Mandal and Sarkar (2012), the MOORA method has a level of flexibility and ease of understanding and separates the subjective part of an evaluation process into decision weight criteria with several decision-making attributes. This method has a good level of selectivity in determining an alternative. Where the criteria that have a beneficial value are (benefit) or that do not have a benefit (cost).

According to Attri and Grover (2013), the MOORA approach is defined as a simultaneous process in order to optimize two or more conflicting with several constraints. The steps of the MOORA method.

1. Inputting Criteria Values

Determining the goal to identify the evaluation attribute in question and input the criterion value in an alternative where the value will later be processed and the results will become a decision (Nugroho, 2018)

\section{Decision Matrix}

Represents all available information for each attribute in the form of a decision matrix. The data in equation (1) represents a matrix Xmxn. (Hengky and Winpec, 2011) Where Xin is the performance measurement of the alternative $I$ the in the attribute $j$ the, $m$ is the number of alternatives and $n$ is the number of attributes / criteria. Then a ratio system is developed in which each performance of an alternative to an attribute is compared with the denominator which represents all the alternatives of that attribute. The following is the change in the criteria value into a decision matrix (1)

$$
\boldsymbol{X}=\left[\begin{array}{ccccc}
x_{11} & \ldots & x_{1 i} & \ldots & x_{1 n} \\
\vdots & \ddots & \vdots & \ddots & \vdots \\
x_{j 1} & \ldots & x_{i j} & \ldots & x_{j n} \\
\vdots & \ddots & \vdots & \ddots & \vdots \\
x_{m 1} & \ldots & x_{m i} & \ldots & x_{m n}
\end{array}\right]
$$

Information (1)

$\mathrm{Xij}=$ alternative response $\mathrm{j}$ to criterion $\mathrm{i}$

$\mathrm{i}=1,2,3,4, \ldots, \mathrm{n}$ is the sequence number of the attribute or criterion

$\mathrm{j}=1,2,3,4, \ldots, \mathrm{m}$ is the alternative number

$\mathrm{X}=$ Decision Matrix

\section{Normalized Matrix}

Normalization aims to unify each matrix element so that the elements in the matrix have uniform values (Nurdin, 2012). Ratio (2)

$$
X^{*}{ }_{i j}=\frac{x_{i j}}{\sqrt{\left[\sum_{\mathrm{j}=1}^{\mathrm{m}} x_{\mathrm{ij}}^{2}\right]}}
$$

Remarks (2)

$\mathrm{Xij}=$ alternative response $\mathrm{j}$ to criterion $\mathrm{i}$

$\mathrm{i}=1,2,3,4, \ldots, \mathrm{n}$ is the sequence number of the attribute or criterion

$\mathrm{j}=1,2,3,4, \ldots, \mathrm{m}$ is the alternative number

$\mathrm{X} * \mathrm{ij}=$ alternative normalization matrix $\mathrm{j}$ on criterion $\mathrm{i}$

4. Calculating Optimization Value

1) If the attributes or criteria for each alternative are not given weight values.

The normalized measure is added in the case of maximization (for favorable attributes) and reduced in minimization (for unprofitable attributes) or in other words reducing the maximum and minimum values for each row to get the ranking on each row, if formulated (3)

$$
y_{j}^{*}=\sum_{i=1}^{i=g} x_{i j}^{*}-\sum_{i=g+1}^{i=n} x_{i j}^{*},
$$

Remarks (3)

$\mathrm{i}=1,2,3, \ldots, \mathrm{g}$ is the criterion attribute with maximized status

$\mathrm{j}=\mathrm{g}+1, \mathrm{~g}+2, \ldots, \mathrm{n}$ are attributes or criteria with minimized status

$\mathrm{y} * \mathrm{j}=$ alternative max-min Normalization Matrix $\mathrm{j}$ 
2) If the attributes or criteria for each alternative are given weight of importance.

Assigning weight values to the criteria, provided that the maximum criteria specific gravity values are greater than the minimum criteria specific gravity values.

To indicate that an attribute is more important it can multiplied by the appropriate weight (coefficient of significance) (Wibobo, 2019)

The following is the formula for calculating the value of MOORA Multi Objective Optimization, the multiplication of the criteria weight to the maximum attribute value minus the multiplication of the criteria weight against the minimum attribute value, if formulated

$$
y_{i}=\sum_{j=1}^{g} w_{j} x_{i j}^{*}-\sum_{j=g+1}^{n} w_{j} x_{i j}^{*}
$$

Description (4)

$\mathrm{I}=1,2,3, \ldots, \mathrm{G}$ is the criterion attribute with maximized status

$\mathrm{j}=\mathrm{g}+1, \mathrm{~g}+2, \ldots, \mathrm{n}$ are attributes or criteria with minimized status

$\mathrm{Wj}=$ weight to alternative $\mathrm{j}$

$\mathrm{y} * \mathrm{j}=$ normalized assessment value of alternative $\mathrm{j}$ for all attributes

5. Determine the Rank Value from the results of the MOORA calculation

The value of yi can be positive or negative depending on the maximum total (favorable attribute) in the decision matrix. A ranking order of yi denotes the last choice (Hidayatullah, 2012). Thus the best alternative has the highest yi value while the worst alternative has the lowest yi value.

The output of the MOORA method calculation.

1) The alternative that has the highest final value (yi), then this alternative is the best alternative from the existing data, this alternative will be chosen according to the existing problems because this is the best choice.

2) Meanwhile, the alternative that has the lowest final value (yi) is the worst alternative from existing data. (Utami, 2012)

\section{F. Decision Making Process}

In the decision-making process, there are stages that must be passed. The stages that must be passed in the decision-making process are as follows:

1. Understanding stage

This stage is the process of tracing and detecting the scope of the problematic and problem recognition process. Input data are obtained, processed and tested in order to identify problems.

2. Design Stage

This stage is the process of finding and developing alternatives. This stage includes the process of understanding the problem, deriving the solution and testing the feasibility of the solution.

\section{Selection Stage}

At this stage, the process of selecting among various alternative actions that may be carried out is carried out. This stage includes searching, evaluating, and recommending solutions that are suitable for the model that has been created. The solution of the model is a specific value for the outcome variable in the chosen alternative (Korniawati, 2017)

4. Implementation Stage

The implementation stage is the implementation stage of the decisions taken. At this stage it is necessary to formulate a series of planned actions, so that the results of decisions can be monitored and adjusted if improvements are needed (Sari, 2018)

\section{RESEARCH METHODS}

\section{A. Flowchart system}

The flowchart system in Picture 1 shows the process flow in the Decision Support System for beneficiaries of the Family Hope Program "PKH" in Kelinjau Ulu Village, Muara Analog District, from the login page enter the main page then there are several menus such as, Data input for potential recipients, Input Criteria , Input subcriteria, MOORA calculation and print the calculation results (Indra, 2010)

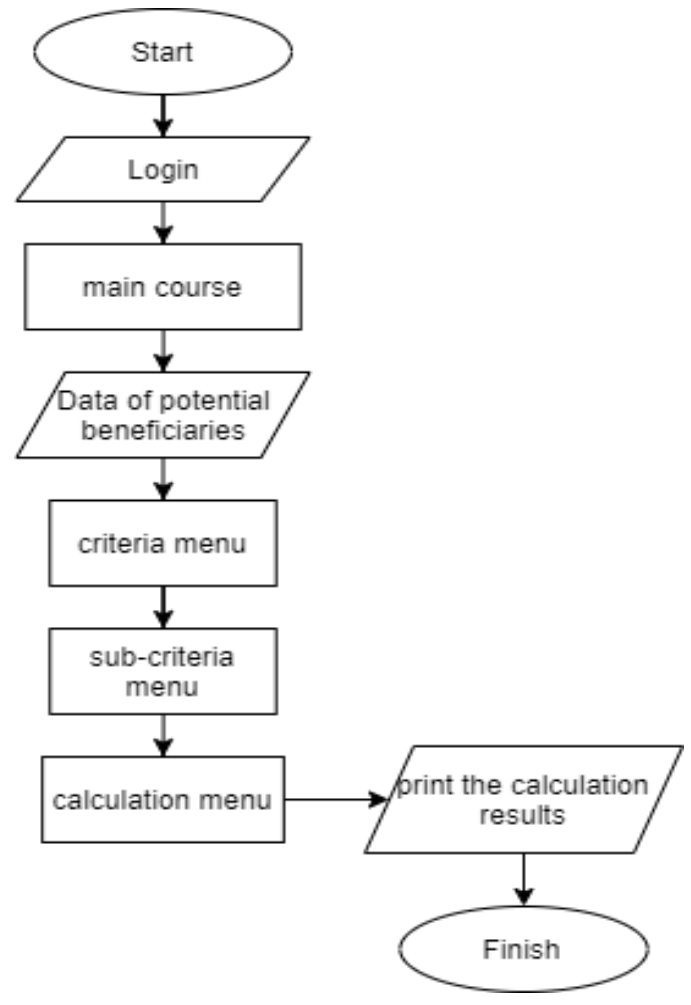

Picture 1. Flowchart of SPK Beneficiaries of the Family Hope Program "PKH"

\section{B. Database Structure}

Table 1 is used to store User data. Table 2 is used to store data on potential beneficiaries. Table 3 is used to 
Arsita, Salmon, \& Pratiwi, H. (2021). Implementation of Multi Objective Optimization on the Basic of Ratio Analysis Method in Decision Support System for Hope Family Program Assistance Recipients in Kelinjau Ulu Village. TEPIAN, 2(4). https://doi.org/10.51967/tepian.v2i4.351

store criteria data. Table 4 is used to store Sub-criteria data, and the last, Table 5 is used to store calculation data

Table 1. Login Table

\begin{tabular}{|l|l|l|l|}
\hline Field Name & Type & Range & Information \\
\hline Username & Varchar & 10 & Username \\
\hline Password & Varchar & 10 & Password \\
\hline
\end{tabular}

Table 2. Recipients

\begin{tabular}{|l|l|l|l|}
\hline Field Name & Type & Range & Information \\
\hline NIK & Number & 16 & NIK number \\
\hline $\begin{array}{l}\text { KK__ } \\
\text { Number }\end{array}$ & Number & 16 & $\begin{array}{l}\text { Family } \\
\text { Number }\end{array}$ \\
\hline Name & Text & 50 & $\begin{array}{l}\text { Name } \\
\text { Prospective } \\
\text { Recipient }\end{array}$ \\
\hline Place of birth & Text & 50 & Place of birth \\
\hline Date of birth & Date & - & Date of birth \\
\hline Address & Text & 100 & Address \\
\hline Gender & Text & 15 & Gender \\
\hline Status & Text & 15 & Marital status \\
\hline $\begin{array}{l}\text { The number of } \\
\text { dependents }\end{array}$ & Varchar & 10 & $\begin{array}{l}\text { The number of } \\
\text { dependents }\end{array}$ \\
\hline $\begin{array}{l}\text { Mother_- } \\
\text { Condition }\end{array}$ & Text & 20 & $\begin{array}{l}\text { Mother's } \\
\text { condition }\end{array}$ \\
\hline $\begin{array}{l}\text { Disabilities } \\
\text { Education_- } \\
\text { Children }\end{array}$ & Text & 20 & $\begin{array}{l}\text { Persons } \\
\text { Disabilities }\end{array}$ \\
\hline
\end{tabular}

Table 3. Criteria Table

\begin{tabular}{|c|c|c|c|}
\hline Field Name & Type & Range & Information \\
\hline Code & Varchar & 10 & Criteria Code \\
\hline Criteria & Text & 20 & Criteria \\
\hline Weight & Number & 10 & Value Criteria \\
\hline
\end{tabular}

Table 4. Sub-criteria table

\begin{tabular}{|c|c|c|l|}
\hline Field Name & Type & Range & \multicolumn{1}{|c|}{ Information } \\
\hline Code & Varchar & 10 & Criteria Code \\
\hline Kode_Sub & Varchar & 10 & $\begin{array}{l}\text { Sub criteria } \\
\text { Code }\end{array}$ \\
\hline Sub criteria & Text & 20 & Sub criteria \\
\hline Weight Sub & Number & 10 & $\begin{array}{l}\text { Sub criteria } \\
\text { Value }\end{array}$ \\
\hline
\end{tabular}

Table 5. Count Table

\begin{tabular}{|l|l|l|l|}
\hline $\begin{array}{l}\text { Field } \\
\text { Name }\end{array}$ & Type & Range & Information \\
\hline NIK & Varchar & 16 & $\begin{array}{l}\text { NIK } \\
\text { number }\end{array}$ \\
\hline Name & Text & 50 & $\begin{array}{l}\text { Name of } \\
\text { Prospective } \\
\text { Recipient }\end{array}$ \\
\hline Education & Text & 20 & Education \\
\hline Disabilities & Number & 10 & $\begin{array}{l}\text { Sub criteria } \\
\text { Value }\end{array}$ \\
\hline
\end{tabular}

\section{RESULT AND DISCUSSION}

A. Login page

In Picture 2, there is a Login page display which contains the Username and Password that must be filled in by the user. In this system, there are two access rights to enter this system, namely the Admin and the Leader, each of which has a Username and Password.

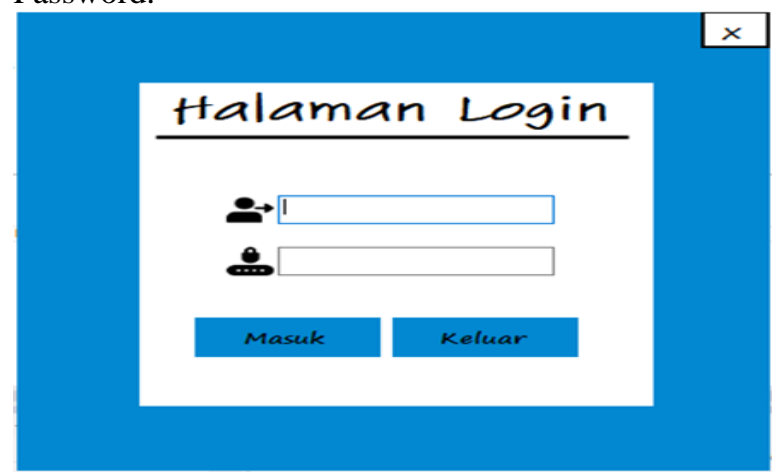

Picture 2. Login page

\section{B. Admin page}

In Picture 3 starting from the main admin page, which consists of the input menu for potential recipients used to enter data for potential beneficiaries, the SPK Criteria menu to see existing criteria and sub-criteria, the MOORA calculation menu is used to perform SPK calculations.

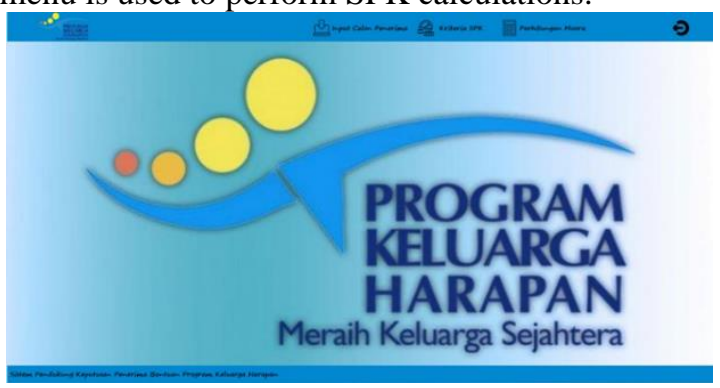

Picture 3. Admin page

\section{Potential Recipient Input page}

In Picture 4 there are NIK (Identity Number), KK Number (Family Card), Name, Place of Birth, Date of Birth, Address, Gender, Status, Number of Dependents, Mother's Condition, Persons with Disabilities, and Children's Education which are used to enter data prospective recipients of "PKH" assistance (Family Hope Program). There is an add button that is used to add data for potential beneficiaries, then a save button to store data for beneficiaries that have been added, a change button to change data when changes occur, and a delete button is used to delete potential recipient data if an error occurs. 


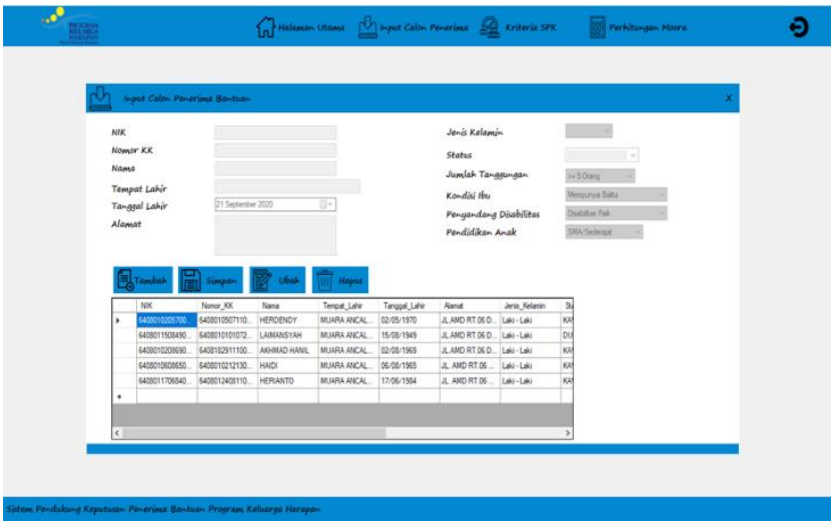

Picture 4. Input Page of Potential Recipients of Assistance

\section{Criteria page}

Picture 5 shows the criteria code, criteria name, subcriteria code, sub-criteria name, criteria weight, and subcriteria value. This page only displays data criteria and sub-criteria cannot change or delete existing data because the data displayed is static or cannot change.

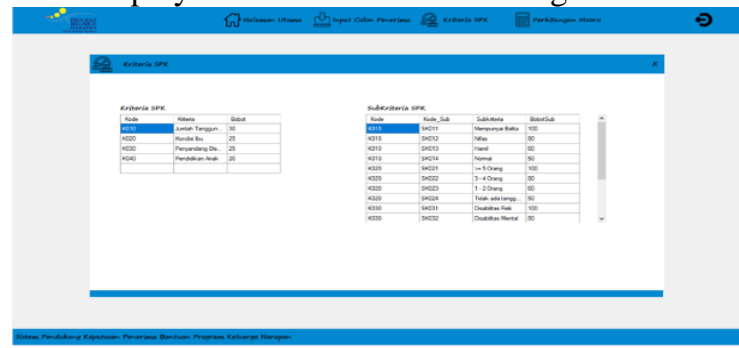

Picture 5. Criteria page

\section{E. MOORA Calculation page}

In Picture 6, it consists of the name of the prospective recipient, the number of dependents, the condition of the mother, the person with disabilities, and the child's education which is used to enter the name of the prospective recipient and the value of the criteria, then there is an add button that functions to add the names of potential beneficiaries, the save button for save the prospective recipient's data and its value, the calculation process button to see the MOORA calculation process, and the print button to print the calculation result report.

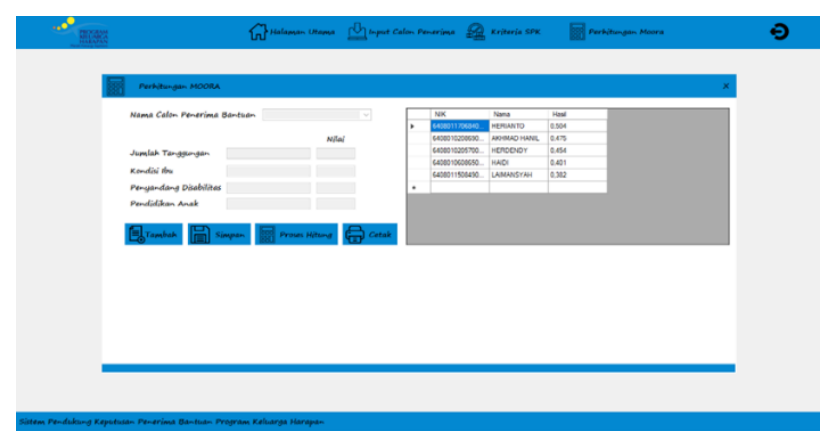

Picture 6. MOORA Calculation Page and Leadership

\section{F. Calculation Process Display}

Picture 7 shows the process of calculating MOORA with steps, namely, making a decision matrix, normalizing the matrix, optimizing the value, the result of addition and subtraction (Max - Min), then the calculation results.

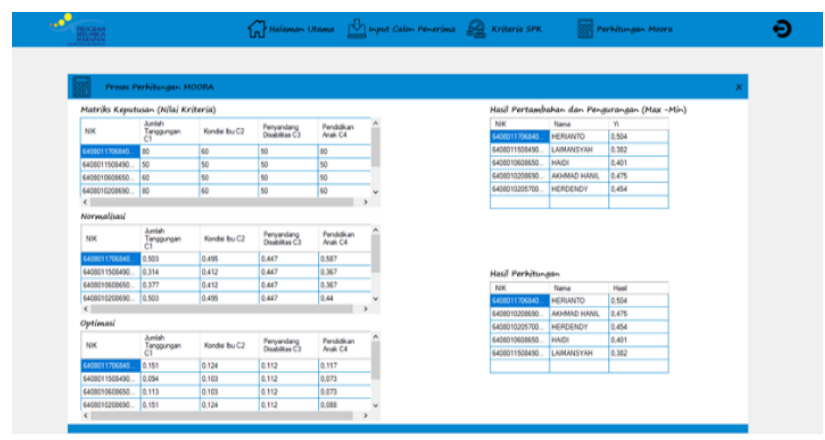

Picture 7. Display Calculation Process

\section{G. Calculation Result Report}

In Picture 8 is a display of the calculation results report used by the leader to view and print the calculation results containing the values sorted from the highest value to the lowest value.

\begin{tabular}{|c|c|c|c|c|c|c|}
\hline \multicolumn{7}{|c|}{$\begin{array}{l}\text { CALON PENERIMA BANTUAN } \\
\text { PROGRAM KELUARGA HARAPAN (PKH) } \\
\text { Desa Kelinjau Ulu Kecamatan Muan Ancalong }\end{array}$} \\
\hline \multicolumn{7}{|c|}{ LAPORAN HASIL PERHITUNGAN } \\
\hline NIK & Nama & Tanggungan & Kondisi lbu & Ditabilitas & Pend idikan & Hatil \\
\hline 6408011706840002 & HERIANTO & 80 & 60 & 60 & 80 & 0,504 \\
\hline 6408010208690001 & AKHMAD HANII & 80 & 60 & 60 & 60 & 0,475 \\
\hline 6408010205700005 & HERDENDY & 80 & so & 60 & 60 & 0,454 \\
\hline 6408010608650001 & HAIDI & 60 & 50 & 60 & 50 & 0,401 \\
\hline 6408011508490001 & LAIMANSYAH & 50 & 50 & 60 & 50 & 0,382 \\
\hline \multicolumn{6}{|c|}{$\begin{array}{l}\text { Hasil akhir dari SPK metode MOORA ini adal ah dengan hasil } 0,504 \\
\text { dipilih sebagai altermatif terbaik. }\end{array}$} & $\begin{array}{l}\text { D192021 } \\
\text { eagelola PXH }\end{array}$ \\
\hline
\end{tabular}

Picture 8. Calculation Result Report

\section{CONCLUSION}

Decision Support System for Family Hope Program Assistance Recipients "PKH" in Kelinjau Ulu Village was built using the MOORA (Multi Objective Optimization on the Basic of Ratio Analysis) method, design and manufacture using Visual Basic.NET programming language and Microsoft Access as the database. This Decision Support System has immutable criteria. This Decision Support System can facilitate decision making and provide recommendations to leaders regarding more targeted beneficiary candidates.

\section{REFERENCES}

Rosa. A. S, and Saladin. 2013. Software Engineering (Structured and Object Oriented). Bandung: Informatics

Asropudin, P., 2013. Dictionary of Information Technology. Bandung: Titian of Science

Attri. R, and Grover, S., 2013. Decision Making Over the Production System Life Cycle: MOORA Method. 
International Journal of System Assurance Engineering Management 5 (3), pp. 320-328.

Badudu, and Zain, S. H, 2011. The effectiveness of Indonesian, Jakarta: Balai Pustaka

Hengky, AM, and Winpec, S., 2011. Creating Database Applications with Visual Basic 6.0. Jakarta: PT Elex Media Komputindo.

Hidayatullah, P., 2012. Visual Basic .NET makes Database Applications and Creative Programs, Bandung: Informatics.

Indra. Y, B., 2010, Flowcharts, Algorithms and Programming Using the $\mathrm{C}++$ Builder Language.

Korniawati, 2017. Decision Support System for Employee Performance Appraisal Using the Profile Matching Method at the Bazaar Laptop Samarinda Store.

Ladjamudin, A. B, 2013. Analysis of Information Systems. Yogyakarta: Graha Science.

Lamsi R. Z, 2019. Decision Support System for Employee Performance Appraisal Using the MultiObjective Optimization Method On The Basis Of Ratio Analysis (MOORA) Based on WEB at the National Narcotics Agency of East Kalimantan Province.

Madcoms, 2011. Proficient in 7 days Microsoft Visual Basic 6.0 \& Crystal Report 2008. Yogyakarta: Andi Offset

Mandal, UK and Sarkar, B. 2012. Selection of Best Intelligent Manufacturing System (IMS) Under Fuzzy MOORA Conflicting MCDM Environment, International Journal of Emerging Technology and Advanced Engineering, 2, pp. 301-310.

Mulyadi. 2010. Accounting Systems, third edition. Jakarta: Publisher Salemba Empat.

Nugroho, P. A, 2018. Decision Support System for Selection of Private High Schools Using the MOORA Method

Nurdin, B. 2012. Decision Support Systems, Computing and Simulation. Yogyakarta: Graha Science.

Nofriansyah, D. 2017. Multi Criteria Decision Making (MCDM) in Decision Support Systems. Yogyakarta: Dee publish.

Romney, M. B and P. John S. 2014. Accounting Information Systems, Thirteenth Edition. Jakarta: Andi

Sari, F. 2018. Methods in decision making. Yogyakarta: Dee publish.

Utami, AB 2012. Web-Based Decision Support System for determining Scholarship Recipients Using the AHP TOPSIS Method. Research, Faculty of Engineering, Diponegoro University, Semarang.

Wibowo, BA 2011. Design and Implementation of Decision Support Systems for Roads Using the ID3 Stuid Method The Case of BAPPEDA in Salatiga City. Satya Wacana Christian University: Central Java. 